Article

\title{
Agricultural Drought Trends on the Iberian Peninsula: An Analysis Using Modeled and Reanalysis Soil Moisture Products
}

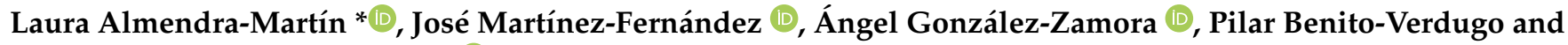 \\ Carlos Miguel Herrero-Jiménez (1)
}

check for

updates

Citation: Almendra-Martín, L.;

Martínez-Fernández, J.;

González-Zamora, Á.;

Benito-Verdugo, P.; Herrero-Jiménez,

C.M. Agricultural Drought Trends on the Iberian Peninsula: An Analysis Using Modeled and Reanalysis Soil Moisture Products. Atmosphere 2021, 12, 236. https://doi.org/10.3390/ atmos12020236

Academic Editor: Sonia

Raquel Gámiz-Fortis

Received: 20 January 2021

Accepted: 4 February 2021

Published: 9 February 2021

Publisher's Note: MDPI stays neutral with regard to jurisdictional claims in published maps and institutional affiliations.

Copyright: (C) 2021 by the authors. Licensee MDPI, Basel, Switzerland. This article is an open access article distributed under the terms and conditions of the Creative Commons Attribution (CC BY) license (https:/ / creativecommons.org/licenses/by/ $4.0 /)$.
Instituto Hispano Luso de Investigaciones Agrarias, CIALE, Universidad de Salamanca, Villamayor, 37185 Salamanca, Spain; jmf@usal.es (J.M.-F.); aglezzamora@usal.es (Á.G.-Z.); pilarbv@usal.es (P.B.-V.); cmhj@usal.es (C.M.H.-J.)

* Correspondence: lauraalmendra@usal.es

Abstract: Drought has a great impact on agriculture and food security, and climate change is increasing its frequency and exacerbating its intensity. Given the enormous interest in studying the recent drought evolution, in this work, agricultural drought trends over the past four decades on the Iberian Peninsula (IP) were analyzed. A trend analysis was performed with soil moisture based on the study of the evolution of anomalies and the Soil Water Deficit Index (SWDI). Two soil moisture databases (Lisflood and ERA5-Land) were used and the analysis was performed at daily and weekly temporal scales. Climate characteristics and soil properties were also considered to detect whether a trend spatial pattern could be identified. The results have shown a clear predominance of negative trends. A marked temporal pattern with negative trends was obtained over a 10-month period that coincided with the growing season of most of the crops on the IP, while a positive trend was observed over 2 months. No differences were found based on the climatic zone or soil characteristics. However, negative trends were observed to decrease as the clay content increased. These results can provide useful information for better water management and agriculture of the IP and other Mediterranean areas.

Keywords: agricultural drought; soil moisture; Iberian Peninsula; trend analysis; climate change

\section{Introduction}

Drought is one of the natural hazards that has the most consequences and the greatest impact on human activities and population [1,2]. Under a scenario of uncertainty and climate change, it is expected that most water-related processes will be negatively affected, and the hydrological extremes will be exacerbated [3]. Global warming has accelerated hydrological processes, first by increasing the energy available for evapotranspiration and, second, by increasing the temperature and thus, the water holding capacity of the atmosphere [4]. Consequently, it results in more intense, widespread, and persistent extreme climatic events, such as droughts [5].

Among the three main categories of drought, i.e., meteorological, hydrological, and agricultural drought [6], agricultural drought has a more direct, immediate, and sensitive impact. An agricultural drought is considered to occur when the soil moisture availability to plants drops to such a level that it adversely affects the crop yield and, hence, agricultural production [7]. Consequently, drought is a major cause of limited productivity in rainfed agrosystems throughout the world, accounting for a large proportion of crop losses and annual yield variations in crops [8]. However, it is not just the direct impact on agriculture or food security [9]. Agricultural drought has been considered a direct factor of social and political conflicts in developing countries since it could have a catalytic effect, contributing to political unrest [10] and affecting the population in aspects that extend beyond feeding [11]. 
Southern Europe is expected to be particularly vulnerable to climate change, at least in all environmental and social aspects that depend on water resources [12]. Droughts can have strong impacts in water-limited areas, such as the Mediterranean region, particularly for countries relying on rainfed agricultural production and in areas in which irrigation plays an important role [13]. The Intergovernmental Panel on Climate Change (IPCC) warned about the possible intensification of droughts in this century, especially in some areas, such as the Mediterranean Basin [14]. Despite this proclivity, few studies have focused on studying agricultural drought trends in Mediterranean countries. Studies have focused on drought trends, particularly hydrological or meteorological drought [15]. Divrak et al. [16] studied the impact of drought on agricultural production in the Mediterranean Basin from a meteorological drought point of view. Jimenez-Donaire et al. [17] evaluated the impact of future changes in the temperature and precipitation regime of Spain on agricultural droughts. Peña-Gallardo et al. [18] studied the impact of drought on cereal productivity in Spain using several meteorological drought indices. Bouras et al. [19] evaluated the impact of agricultural drought on cereal yields in Morocco using remote sensing indices.

The Iberian Peninsula (IP) is among the especially vulnerable areas of southern Europe [14] due to its location as an ecotone between arid and humid regions, its climatic characteristics, and its agricultural predominance. Spain and Portugal account for $17.2 \%$ [20] of the utilized agricultural area of the European Union. Almost half (47.3\%) of the IP territory has agricultural use, and only $4.8 \%$ is irrigated [21]. The rest of the agricultural land is rainfed, whether for permanent or annual crops or pastures, and exclusively depends on the water provided by the atmosphere and stored in the soil. Climate projections for the present century indicate overall increases in the area suitable for rainfed agriculture in temperate dryland regions, although the regional exception to this trend is Europe, especially the southern part, where suitability in temperate dryland areas will decline substantially [22].

According to its definition, agricultural drought is identified by a soil water shortage. Therefore, soil moisture observations are the appropriate approach for agricultural drought analysis, considering, as well, that plant water stress is more strongly related to the relative amount of plant-available water in the soil than to the absolute amount of soil moisture [23]. In the past, agricultural drought has usually been studied using methods based on longterm atmospheric data, such as rainfall and temperature, or on precipitation indices [24] that, in fact, were close to meteorological drought approaches. In recent years, new methods for agricultural drought monitoring and assessment using soil moisture have been proposed. These methods use soil moisture obtained from in situ measurements [25], modeling [26], reanalysis [27] or remote sensing [28] as the defining variable [29] or in a combined approach $[30,31]$.

The main restriction for trend analysis is the availability of long enough data series. Therefore, agricultural drought trend analysis was difficult to address due to a lack of long series of appropriate soil moisture databases, in terms of spatial and temporal scales. However, long-term soil moisture databases are currently available, even globally, that allow for use in applications that were not possible until recently. These databases come from remote sensing [32], modeling or reanalysis [33,34], have been validated with very satisfactory results, and provide decades-long series of soil profile moisture data at everfiner temporal and spatial scales. In the case of remote sensing databases, the series still have a limited length since the launch of satellites dedicated specifically to soil moisture observations, such as Advanced Scatterometer (ASCAT, 2007), Soil Moisture and Ocean Salinity (SMOS, 2010) or Soil Moisture Active Pasive (SMAP, 2015), has been relatively recent. The Soil Moisture Climate Change Initiative soil moisture dataset [32], from the European Space Agency, has the longest series at more than 40 years and has been proven extremely useful for many applications [35]. However, the amount of data available before 2003 in most areas [36] is a limitation for their use in trend analysis. For example, on the IP, the percentage of data availability barely exceeded $20 \%$ in the first 20 years of the series. 
Instead, modeling or reanalysis databases such as the Global Land Data Assimilation System (National Aeronautics and Space Administration) or ERA (European Centre for Medium-Range Weather Forecasts) provide several decades of series of global soil moisture data [37].

The main goal of this study has been to analyze agricultural drought trends over the past four decades on the IP, an area which is especially vulnerable and a period in which environmental conditions in this region are significantly changing due to climate change. Trend analysis has been performed with soil moisture based on the study of the evolution of anomalies, a statistic frequently used in this type of analysis, and the Soil Water Deficit Index (SWDI), an indicator that provides agronomic information, as it is based on the identification of plant available water [25]. For this work, two soil moisture databases that have proved to be suitable for the study of soil moisture trends (Lisflood and ERA5-Land) [38,39] were used and the analysis was performed at two temporal scales (daily and weekly). As a secondary objective, it was studied whether differences were observed in the results of trends depending on the climatic conditions or soil characteristics. Knowledge of agricultural drought trends over an environmentally vulnerable region, as the IP, can provide useful information for better water management and agriculture.

\section{Databases and Methodology}

\subsection{Soil Moisture Databases}

\subsubsection{ERA5-Land Soil Moisture}

The reanalysis dataset ERA5-Land (ERA5 hereafter) from the ECMWF provides temporal series of several land variables from 1981 to the present. These series are obtained by replaying the land component of ERA5 but using atmospheric variables as inputs. ERA5 variables, including soil moisture, are provided in a regular grid of $0.1 \times 0.1^{\circ}$, with an hourly temporal resolution [37]. This database has been validated with in situ soil moisture networks worldwide, including the IP [40]. For this study, soil moisture at 12 am and $12 \mathrm{pm}$ and the three depth layers provided by ERA5 were averaged. Thus, the daily series of root zone soil moisture $(0-100 \mathrm{~cm})$ were obtained for the IP from 1981 to 2019.

\subsubsection{Lisflood Soil Moisture}

The Lisflood (LF) hydrological model, used by the European Commission for the prediction and monitoring of natural hazards in Europe, such as floods or droughts, provides outputs of hydrological variables throughout the entire European continent with a $5 \times 5 \mathrm{~km}$ spatial resolution and a daily temporal resolution [41,42]. In this work, the soil moisture series corresponding to the IP was used from January 1991 to December 2019. This variable is provided in three different soil layers for each pixel. The first two layers were selected, containing the first $100 \mathrm{~cm}$ of soil depth. At each pixel, the daily soil moisture value of each of these layers was averaged, thus obtaining a time series of soil moisture for the root zone. This model has been widely used and validated in Europe [43].

\subsection{Ancillary Data}

\subsubsection{Irrigation Mask}

As soil moisture evolution in irrigated areas is controlled by irrigation management, a mask was constructed to exclude these regions from the study. The Food and Agriculture Organization (FAO) has developed the Digital Global Map of Irrigation Areas with a spatial resolution of 5 arc minutes [44]. This map provides the percentage of irrigated areas. In this study, version five of the irrigation map was used to create an irrigation area mask in the IP (Figure 1). First, this map was resampled into the two soil moisture database grids. Then, one mask for each soil moisture database was computed by excluding all the pixels with more than $10 \%$ irrigation area. 


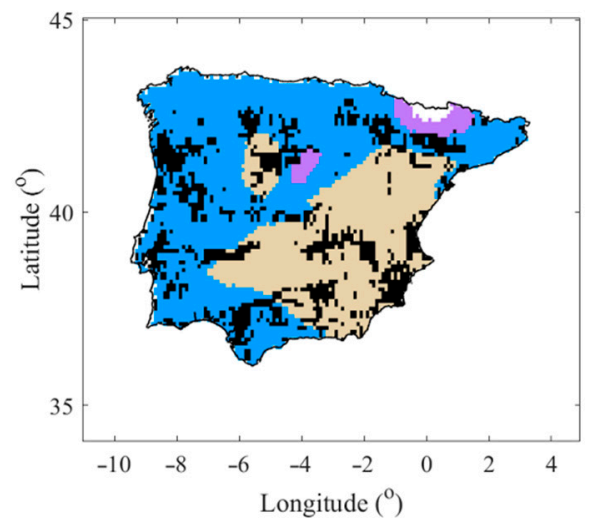

(a)

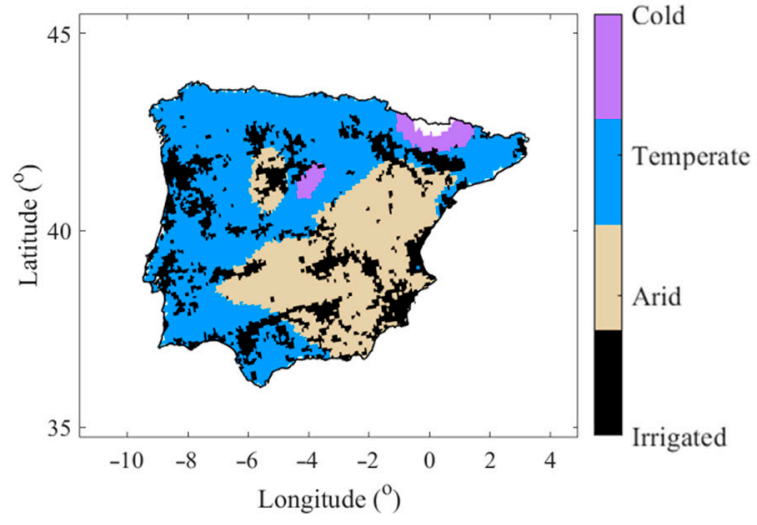

(b)

Figure 1. Climate zone (Köppen-Geiger classification) maps obtained at the European Centre for Medium-Range Weather Forecasts (ERA5) (a) and Lisflood (LF) (b) spatial resolutions. Irrigated areas are marked in black.

\subsubsection{Climate Classification}

The Köppen-Geiger climate classification was used to evaluate whether climatic conditions have an influence on agricultural drought trends. This climate classification assembles the different types of climate worldwide into five principal classes subdivided into up to 30 subcategories. The classification takes into account the temperature and precipitation characteristics of each kind of climate. This classification is widely used and different maps with different characteristics can be found in the literature [45-47]. In this study, the global map produced by [48] with a spatial resolution of $0.1^{\circ}$ was used. This map was resampled into the two soil moisture database grids to obtain one classification for each soil moisture database (Figure 1). In the resulting classification, only the principal classes were considered. Thus, pixels of the IP were classified in the three different types of climate that exist in the region: Arid, temperate, and cold.

\subsubsection{Soil Data}

The ISRIC-World Soil Information database includes the SoilGrids product, which provides information on different chemical and physical soil properties at a spatial resolution of $250 \times 250 \mathrm{~m}$ [49]. The different soil properties are estimated for six depth intervals reaching down to $200 \mathrm{~cm}$. In this study, the first five intervals $(0-100 \mathrm{~cm})$ of sand, clay, and organic matter content were averaged to obtain each depth profile and the resulting maps were resampled into ERA5 and LF grids. They were used to calculate the soil water parameters of the SWDI with the pedotransfer functions (PTFs) proposed by [50]. In addition, sand and clay maps (Figure 2) were used to analyze whether a relationship between agricultural drought trends and the soil texture exists.

\subsubsection{Soil Moisture Climate Change Initiative (CCI) Dataset}

The CCI soil moisture database [32] integrates satellite soil moisture products from different missions that have measured this variable since 1978. It was used to validate the ERA5 and LF series over the IP. The validation was carried out with the coincident period of the three datasets from 1991 to 2019 (Figure 3). First, the reanalysis and modeled databases were resampled into the CCI soil moisture grid. The Pearson correlation coefficient was calculated for each pixel by comparing the CCI with the ERA5 series, the CCI with the LF series, and the ERA5 with the LF. In addition, the Köppen-Geiger climate classification was used to evaluate this correlation in each climatic type region (Figure 3). Good concordance between the three databases was obtained, with correlation coefficients (R) above 0.8 most of the time. When ERA5 and LF were compared, $\mathrm{R}$ was approximately 0.9 for most of the series, which suggests that, despite the different methodologies behind those products, both are similarly suitable. Cold regions showed the worst correlation with CCI, which is 
due to the geographical location of this type of climate. In mountain regions, the retrieval of satellite soil moisture is difficult, which leads to a scarcity and lower accuracy of data. Nevertheless, cold areas are very small in the IP (Figure 1).

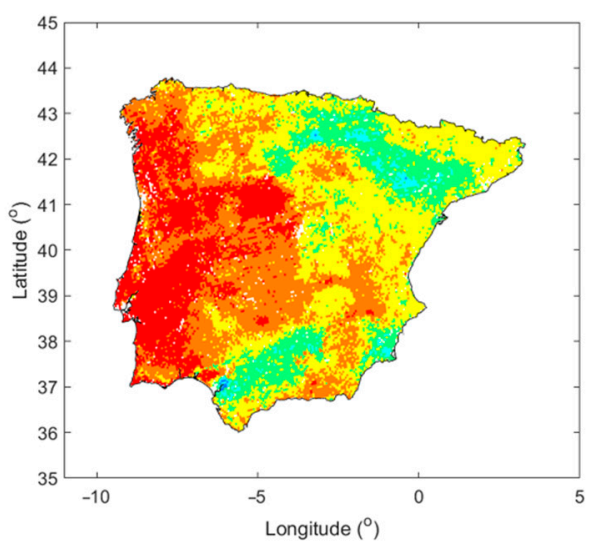

(a)

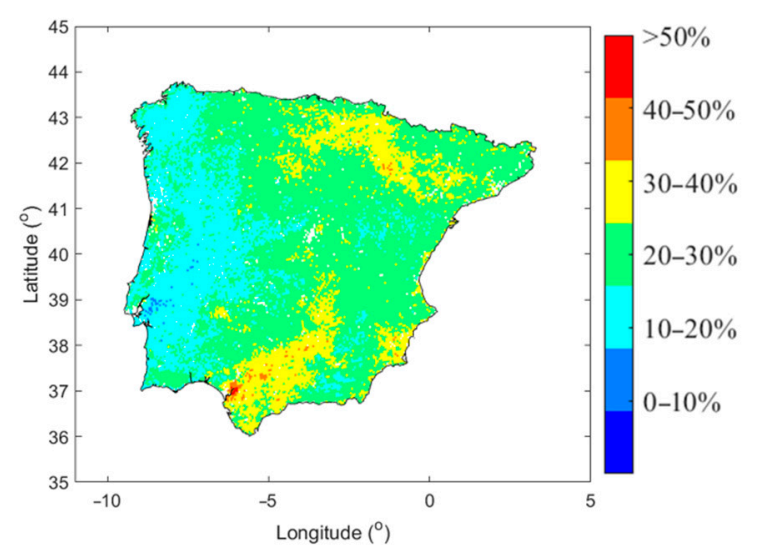

(b)

Figure 2. Sand (a) and clay (b) content of the soils of the Iberian Peninsula.
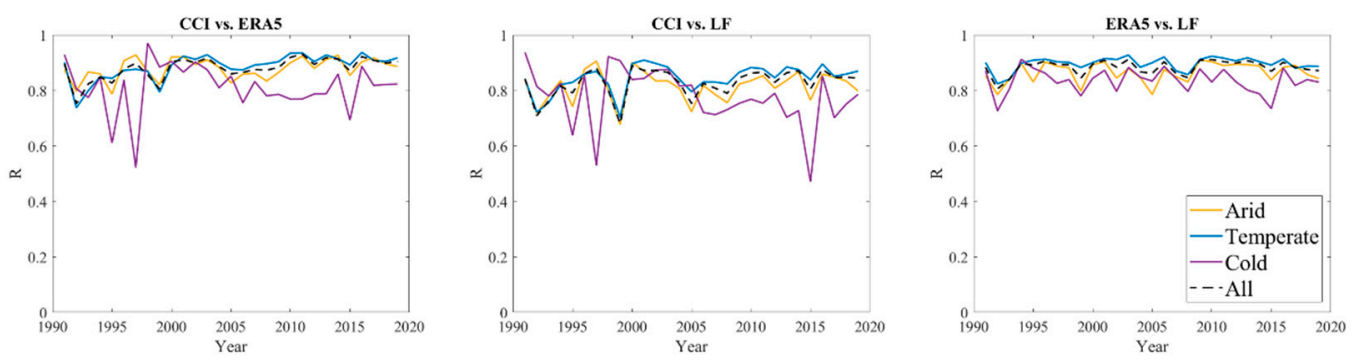

Figure 3. Correlation of LF and ERA5 with climate change initiative (CCI) during the coinciding periods (1991-2019) and by climate zones of the Iberian Peninsula.

\subsection{Drought Indices}

\subsubsection{Soil Moisture Anomalies}

Anomalies of different hydrometeorological variables have been widely used as a drought indicator [51-53]. In this work, the root zone soil moisture anomalies were computed, and the trends of the resulting series were analyzed at daily and weekly resolutions. These two temporal scales were used considering that they are more suitable to analyze agricultural drought [54]. Anomalies were calculated by removing the mean annual cycle from the root zone soil moisture series. This annual cycle was calculated with a monthly average using the entire study period of each root zone soil moisture database, which is a common technique to calculate anomalies of seasonal variables [55]. For the daily temporal resolution, these monthly values were interpolated using a cubic function to obtain a value for each day of the year and the same method was used to calculate a weekly series, similar to what [56] did.

\subsubsection{Soil Water Deficit Index}

The Soil Water Deficit Index (SWDI) was developed for assessing and monitoring agricultural drought through soil moisture [25]. It is calculated as follows:

$$
\mathrm{SWDI}=\left(\frac{\mathrm{SM}-\mathrm{FC}}{\mathrm{AWC}}\right) \times 10
$$


where SM is the soil moisture content, FC is the field capacity value, and AWC (available water content) is the difference between FC and the wilting point (WP). The FC and WP values used to calculate the SWDI were obtained through the PTFs proposed by [50], and the sand, clay, and organic matter content values were obtained from the Soil Grids database. If the SWDI obtained is positive, this indicates that the soil has a water excess, while if the value obtained is negative, this indicates that there is agricultural drought. The water deficit is absolute (wilting point) when the SWDI reaches $\leq-10$, where the soil water content is below the lower limit of the available water for plants [57].

For this study, the SWDI was calculated with the soil moisture data from both the ERA5 and LF databases, both on a daily and weekly scale, for the study periods of each database.

\subsection{Trend Analysis}

The Mann-Kendall (MK) test $[58,59]$ is a commonly used tool to detect monotonic trends [60-63] and in this research, it was used to study agricultural drought trends in the IP. MK is a nonparametric test able to detect whether a series has a significant monotonic trend and if it is positive or negative. For such detection, the $S$ statistic is used and calculated as follows:

$$
S=\sum_{i=1}^{n-1} \sum_{j=1}^{n} \operatorname{sgn}\left(x_{j}-x_{i}\right)
$$

where

$$
\operatorname{sgn}(x)= \begin{cases}1 & \text { if } x>0 \\ 0 & \text { if } x=0 \\ -1 & \text { if } x<0\end{cases}
$$

The sign of $S$ determines whether the series has an upward (positive) or downward trend (negative), although the significance of this trend is given by the statistical parameter Z:

$$
Z= \begin{cases}\frac{S-1}{\sqrt{\operatorname{var}(S)}} & \text { if } S>0 \\ 0 & \text { if } S=0 \\ \frac{S+1}{\sqrt{\operatorname{var}(S)}} & \text { if } S<0\end{cases}
$$

For a $Z$ value and a given significance level $\alpha$, whether $|Z|>Z_{\alpha} / 2$ is met, the trend is considered significant. In this study, the significance level was set to $\alpha=0.05$. Thus, a trend was considered significant for absolute values of $Z$ greater than 1.96 . The $Z$ values were calculated for each pixel of the SWDI and anomaly series of each soil moisture database and each temporal resolution. The two agricultural drought index series considered have different characteristics. The SWDI is a seasonal variable, which means that the data are autocorrelated, as distinct from the anomaly series. This autocorrelation could increase the chance of obtaining a significant trend even if it does not exist [64]. Several methods have been proposed in the literature to avoid this problem [64-66]. However, [67] showed that for a large enough sample, the influence of this autocorrelation is not significant. Thus, $Z$ values were first computed using the entire study period and the simple MK test and the number of significant, positive, and negative trends was analyzed. Then, each month series was individually analyzed and $12 \mathrm{Z}$ values were obtained for each pixel. In this way, the annual dynamics of agricultural drought trends could be studied. Accordingly, the autocorrelation problem is avoided using this approach.

\section{Results and Discussion}

Analyzing the series as a whole and at the scale of the entire IP (Table 1), it is observed that the number of cases with a significant trend is very high, both for anomalies and for SWDI, ranging from $81.5 \%$ to $88.1 \%$ at the daily scale and from $48.9 \%$ to $70.8 \%$ at the weekly scale. For both anomalies and SWDI, and on the two scales of analysis, negative trends clearly dominate, ranging from $76.8 \%$ to $99.8 \%$ of the cases. These results clearly 
indicate that over the past four decades, agricultural drought has increased significantly in the main part of the IP. This is particularly interesting as both agricultural drought indices have a different nature. Soil moisture anomalies have a strictly statistical character, indicating whether the variable indicator significantly deviates from the usual condition for the specific site and period [68], while the SWDI has an agronomic and ecohydrological interpretation [25]. In addition, in view of these results, it was confirmed that the likely autocorrelation [67] that affects the SWDI series does not seem to influence the chance of obtaining significant trends.

Table 1. Percentage of significant $(\mathrm{S})$, positive $(\mathrm{P})$, and negative $(\mathrm{N})$ trends at daily and weekly scales for the whole series. Maximum trend percentage values are in bold.

\begin{tabular}{cccccc}
\hline \multirow{2}{*}{ Index. } & Trend & \multicolumn{2}{c}{ Daily } & \multicolumn{2}{c}{ Weekly } \\
\cline { 3 - 6 } & & ERA5 & LF & ERA5 & LF \\
\hline \multirow{3}{*}{ Anomalies } & $\mathrm{S}$ & 83.2 & 88.1 & 60.3 & 70.8 \\
& $\mathrm{P}$ & 3.2 & 23.2 & 0.6 & 20.4 \\
& $\mathrm{~N}$ & $\mathbf{9 6 . 8}$ & $\mathbf{7 6 . 8}$ & $\mathbf{9 9 . 4}$ & $\mathbf{7 9 . 6}$ \\
\hline \multirow{3}{*}{ SWDI } & $\mathrm{S}$ & 81.5 & 84.8 & 48.9 & 59.3 \\
& $\mathrm{P}$ & 1.5 & 15.8 & 0.2 & 12.6 \\
& $\mathrm{~N}$ & $\mathbf{9 8 . 5}$ & $\mathbf{8 4 . 2}$ & $\mathbf{9 9 . 8}$ & $\mathbf{8 7 . 4}$ \\
\hline
\end{tabular}

If the results are analyzed considering the climatic characteristics from the classification of Köppen-Geiger, the results are very similar (Table 2). In the three identified climate zones (arid, temperate, and cold), the predominance of negative trends is remarkable. The cold zone could be considered outside the analysis since it occupies a very small area of approximately 3\% (Figure 2), mostly in high mountains. However, in both arid and temperate areas, which account for $37 \%$ and $60 \%$ of the IP surface area, respectively, the results are very similar. In all cases, and similar to the whole analysis, negative trends are prevalent and always above $76 \%$ of the cases. It should also be highlighted that in the case of the two indices calculated with the ERA5 database, negative trends are above $95 \%$, both on a daily and weekly basis. Therefore, there do not seem to be noticeable differences between the climatic areas, depending on whether they are rainy or dry or whether the average temperature is high or low.

Table 2. Percentage of significant $(\mathrm{S})$, positive $(\mathrm{P})$, and negative $(\mathrm{N})$ trends at daily and weekly scales and by climate zone (Köppen-Geiger classification). Maximum trend percentage values are in bold.

\begin{tabular}{cccccccccc}
\hline \multirow{3}{*}{ Climate Zone } & \multirow{4}{*}{ Trend } & \multicolumn{3}{c}{ Anomalies } & \multicolumn{4}{c}{ SWDI } \\
\cline { 3 - 10 } & & \multicolumn{2}{c}{ Daily } & \multicolumn{2}{c}{ Weekly } & \multicolumn{2}{c}{ Daily } & \multicolumn{2}{c}{ Weekly } \\
\cline { 2 - 10 } & & ERA5 & LF & ERA5 & LF & ERA5 & LF & ERA5 & LF \\
\hline \multirow{3}{*}{ Arid } & $\mathrm{S}$ & 78.1 & 84.4 & 52.1 & 64.1 & 80.7 & 82.1 & 45.0 & 54.3 \\
& $\mathrm{P}$ & 4.5 & 24.0 & 1.8 & 21.9 & 1.9 & 15.6 & 0.5 & 13.8 \\
& $\mathrm{~N}$ & $\mathbf{9 5 . 5}$ & $\mathbf{7 6 . 0}$ & $\mathbf{9 8 . 2}$ & $\mathbf{7 8 . 1}$ & $\mathbf{9 8 . 1}$ & $\mathbf{8 4 . 4}$ & $\mathbf{9 9 . 5}$ & $\mathbf{8 6 . 2}$ \\
\hline \multirow{3}{*}{ Temperate } & $\mathrm{S}$ & 84.8 & 89.6 & 63.1 & 73.5 & 77.5 & 83.1 & 46.4 & 58.9 \\
& $\mathrm{P}$ & 2.7 & 23.7 & 0.2 & 20.8 & 1.3 & 16.5 & 0.0 & 12.9 \\
& $\mathrm{~N}$ & $\mathbf{9 7 . 3}$ & $\mathbf{7 6 . 3}$ & $\mathbf{9 9 . 8}$ & $\mathbf{7 9 . 2}$ & $\mathbf{9 8 . 7}$ & $\mathbf{8 3 . 5}$ & $\mathbf{1 0 0 . 0}$ & $\mathbf{8 7 . 1}$ \\
\hline \multirow{3}{*}{ Cold } & $\mathrm{S}$ & 97.3 & 94.7 & 90.2 & 85.5 & 97.3 & 88.5 & 89.6 & $\mathbf{7 5 . 5}$ \\
& $\mathrm{P}$ & 0.0 & 13.1 & 0.0 & 8.6 & 0.0 & 7.8 & 0.0 & 2.1 \\
& $\mathrm{~N}$ & $\mathbf{1 0 0 . 0}$ & $\mathbf{8 6 . 9}$ & $\mathbf{1 0 0 . 0}$ & $\mathbf{9 1 . 4}$ & $\mathbf{1 0 0 . 0}$ & $\mathbf{9 2 . 2}$ & $\mathbf{1 0 0 . 0}$ & $\mathbf{9 7 . 9}$ \\
\hline
\end{tabular}

Agricultural drought trends have also been analyzed for each month of the year (Tables 3 and 4 and Figures 4 and 5) using soil moisture anomalies and SWDI, with the aim of identifying whether any temporary patterns exist. There is a marked pattern that includes 10 months with negative trends and 2 months with positive trends, and it is 
similar for both agricultural drought indices calculated with ERA5 and LF. With the results obtained using ERA5 data, a clear predominance of negative trends was obtained from April to January and a positive trend was obtained from February to March. For the results obtained with LF, negative trends predominate from May to February and positive trends predominate in March-April. During the spring and summer months, negative trends usually exceed $70 \%$, and in the case of ERA5, they are above $90 \%$. The maximum number of significant cases was obtained from April-May to October, which coincides with the main part of the growing season.

Table 3. Monthly results of the percentage of significant $(\mathrm{S})$, positive $(\mathrm{P})$, and negative $(\mathrm{N})$ trends at the daily and weekly scales for the soil moisture anomalies. Maximum trend percentage values are in bold.

\begin{tabular}{|c|c|c|c|c|c|c|c|c|c|c|c|c|}
\hline & \multicolumn{6}{|c|}{ Daily } & \multicolumn{6}{|c|}{ Weekly } \\
\hline & \multicolumn{3}{|c|}{ ERA5 } & \multicolumn{3}{|c|}{ LF } & \multicolumn{3}{|c|}{ ERA5 } & \multicolumn{3}{|c|}{ LF } \\
\hline & $S$ & $\mathbf{P}$ & $\mathbf{N}$ & $S$ & $\mathbf{P}$ & $\mathbf{N}$ & $S$ & $\mathbf{P}$ & $\mathbf{N}$ & $S$ & $\mathbf{P}$ & $\mathbf{N}$ \\
\hline $\mathrm{J}$ & 45.2 & 13.9 & 86.1 & 79.6 & 11.2 & 88.8 & 10.8 & 2.3 & 97.7 & 44.8 & 8.1 & 91.9 \\
\hline $\mathrm{F}$ & 52.5 & 69.7 & 30.3 & 71.1 & 42.2 & 57.8 & 19.4 & 75.5 & 24.5 & 35.5 & 46.8 & 53.2 \\
\hline M & 81.3 & 90.3 & 9.7 & 69.9 & 75.2 & 24.8 & 24.0 & 86.4 & 13.6 & 26.7 & 70.4 & 29.6 \\
\hline A & 34.4 & 31.7 & 68.3 & 75.6 & 84.4 & 15.6 & 6.3 & 5.2 & 94.8 & 44.0 & 91.3 & 8.7 \\
\hline $\mathrm{M}$ & 78.0 & 1.8 & 98.2 & 67.0 & 26.8 & 73.2 & 27.1 & 0.0 & 100.0 & 32.6 & 18.9 & 81.1 \\
\hline $\mathrm{J}$ & 90.6 & 1.2 & 98.8 & 74.2 & 24.9 & 75.1 & 54.5 & 0.0 & 100.0 & 34.8 & 28.7 & 71.3 \\
\hline $\mathrm{J}$ & 89.4 & 1.0 & 99.0 & 76.8 & 29.9 & 70.1 & 66.5 & 0.2 & 99.8 & 41.1 & 27.6 & 72.4 \\
\hline A & 93.2 & 0.3 & 99.7 & 81.3 & 18.9 & 81.1 & 75.3 & 0.1 & 99.9 & 50.1 & 13.3 & 86.7 \\
\hline$S$ & 84.3 & 13.5 & 86.5 & 81.7 & 12.9 & 87.1 & 34.3 & 21.9 & 78.1 & 53.8 & 7.8 & 92.2 \\
\hline $\mathrm{O}$ & 71.3 & 27.4 & 72.6 & 90.7 & 1.6 & 98.4 & 30.7 & 1.8 & 98.2 & 65.4 & 0.6 & 99.4 \\
\hline $\mathrm{N}$ & 39.0 & 43.8 & 56.2 & 67.3 & 18.7 & 81.3 & 6.8 & 34.9 & 65.1 & 26.4 & 11.8 & 88.2 \\
\hline $\mathrm{D}$ & 56.9 & 8.0 & 92.0 & 78.3 & 9.1 & 90.9 & 11.1 & 3.7 & 96.3 & 45.2 & 6.1 & 93.9 \\
\hline
\end{tabular}

Table 4. Monthly results of the percentage of significant $(\mathrm{S})$, positive $(\mathrm{P})$, and negative $(\mathrm{N})$ trends at daily and weekly scales for the soil water deficit index (SWDI). Maximum trend percentage values are in bold.

\begin{tabular}{|c|c|c|c|c|c|c|c|c|c|c|c|c|}
\hline & \multicolumn{6}{|c|}{ Daily } & \multicolumn{6}{|c|}{ Weekly } \\
\hline & \multicolumn{3}{|c|}{ ERA5 } & \multicolumn{3}{|c|}{ LF } & \multicolumn{3}{|c|}{ ERA5 } & \multicolumn{3}{|c|}{ LF } \\
\hline & $S$ & $\mathbf{P}$ & $\mathbf{N}$ & $S$ & $\mathbf{P}$ & $\mathbf{N}$ & $S$ & $\mathbf{P}$ & $\mathbf{N}$ & $S$ & $\mathbf{P}$ & $\mathbf{N}$ \\
\hline $\mathrm{J}$ & 43.3 & 11.7 & 88.3 & 80.3 & 10.8 & 89.2 & 9.9 & 0.6 & 99.4 & 45.5 & 7.6 & 92.4 \\
\hline $\mathrm{F}$ & 52.7 & 69.0 & 31.0 & 71.4 & 41.1 & 58.9 & 19.4 & 74.4 & 25.6 & 35.6 & 45.6 & 54.4 \\
\hline M & 81.1 & 89.9 & 10.1 & 67.9 & 73.0 & 27.0 & 23.0 & 85.5 & 14.5 & 25.2 & 66.4 & 33.6 \\
\hline A & 33.0 & 26.4 & 73.6 & 73.6 & 82.7 & 17.3 & 6.4 & 3.3 & 96.7 & 41.9 & 90.1 & 9.9 \\
\hline M & 80.5 & 0.5 & 99.5 & 67.9 & 22.6 & 77.4 & 25.8 & 0.0 & 100.0 & 32.9 & 16.8 & 83.2 \\
\hline $\mathrm{J}$ & 93.6 & 0.7 & 99.3 & 75.4 & 19.8 & 80.2 & 59.9 & 0.0 & 100.0 & 36.2 & 20.5 & 79.5 \\
\hline $\mathrm{J}$ & 94.2 & 0.4 & 99.6 & 77.5 & 23.9 & 76.1 & 74.7 & 0.1 & 99.9 & 41.7 & 18.8 & 81.2 \\
\hline A & 93.7 & 0.3 & 99.7 & 81.7 & 19.1 & 80.9 & 77.6 & 0.1 & 99.9 & 49.6 & 14.1 & 85.9 \\
\hline$S$ & 81.3 & 11.1 & 88.9 & 78.8 & 19.7 & 80.3 & 30.6 & 20.4 & 79.6 & 46.6 & 15.1 & 84.9 \\
\hline $\mathrm{O}$ & 68.4 & 32.0 & 68.0 & 87.9 & 2.3 & 97.7 & 25.5 & 3.5 & 96.5 & 52.7 & 1.1 & 98.9 \\
\hline $\mathrm{N}$ & 36.1 & 45.5 & 54.5 & 65.9 & 21.2 & 78.8 & 6.2 & 38.8 & 61.2 & 23.1 & 15.7 & 84.3 \\
\hline D & 53.3 & 7.9 & 92.1 & 77.2 & 9.4 & 90.6 & 10.5 & 3.8 & 96.2 & 44.7 & 6.6 & 93.4 \\
\hline
\end{tabular}



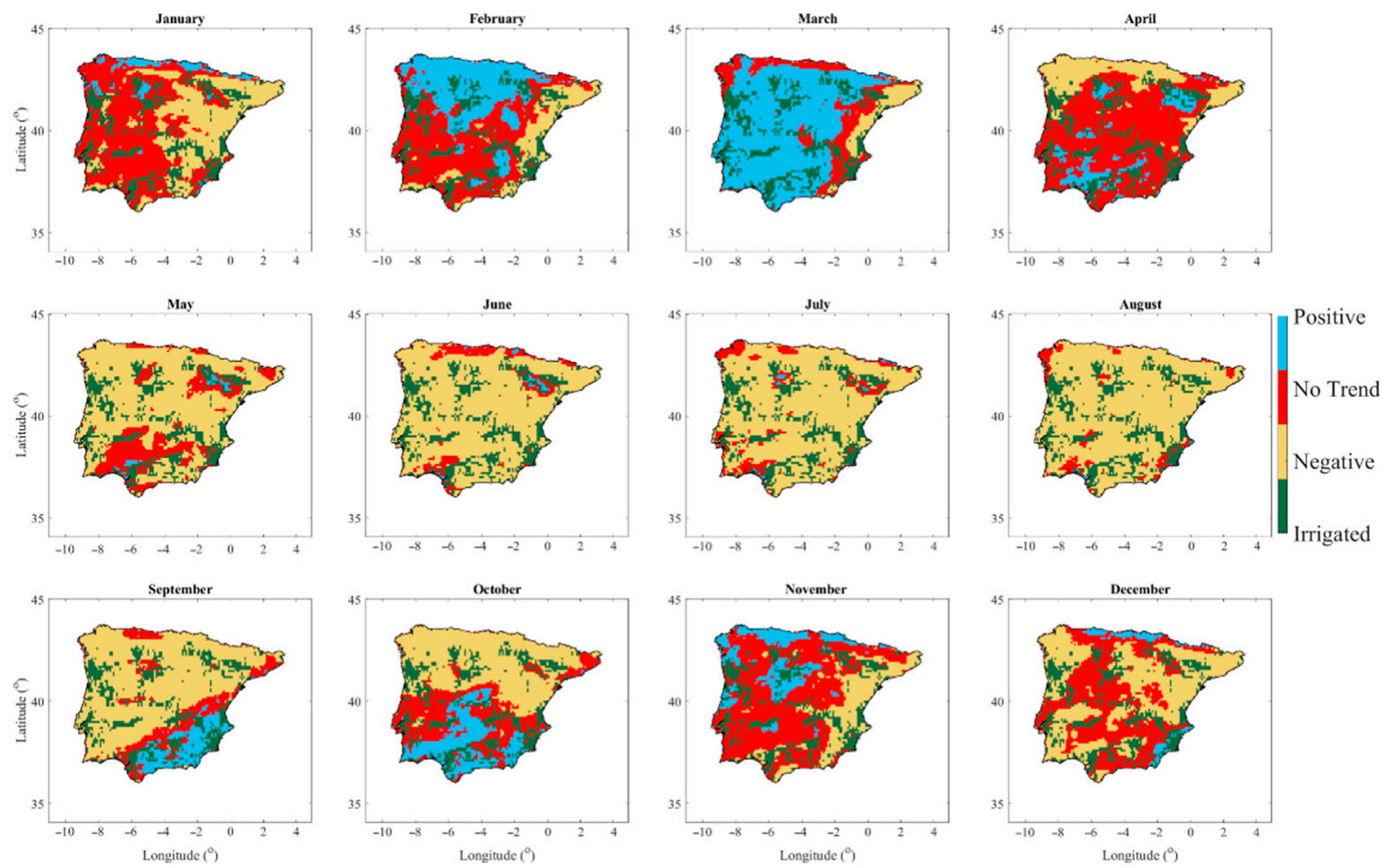

Figure 4. Monthly results of the soil moisture anomalies trends obtained with ERA5 data (daily scale).
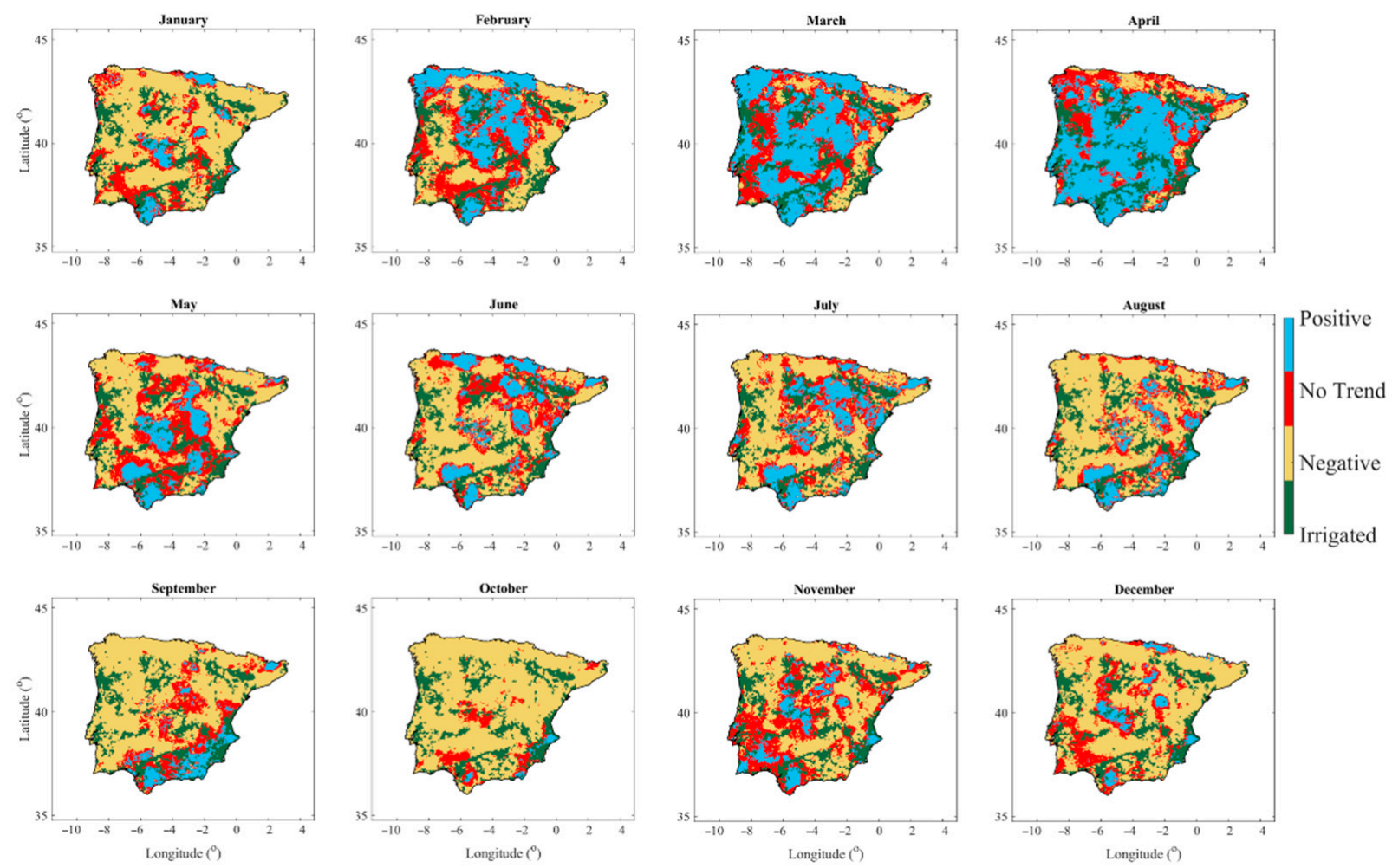

Figure 5. Monthly results of the soil moisture anomalies trends obtained with LF data (daily scale).

A differentiation between the results obtained with both soil moisture products is well observed in the monthly maps (Figures 4 and 5). The clearest difference between the results of both products is observed in the summer months. While with ERA5, the spatial predominance of negative trends is absolute during those months in most IP, with 
LF, even if negative trends clearly predominate, there are certain areas with positive trends, especially from May to July. Most of these positively trend areas in those months coincide with areas where soil texture is finer (Figure 2), which could indicate that this soil characteristic could be related to the behavior of agricultural drought indices calculated with LF. This differentiation may also be related to the intrinsic differences of both products. While LF soil moisture is a mere modeling product, ERA5 is a reanalysis product with satellite soil moisture assimilation. That is, in the first case, soil moisture is obtained from modeling from, fundamentally, climate data and the reliability of the results also depends on the suitability of the meteorological ground stations networks [68]. In the second, the modeling also implies the assimilation of the observed satellite soil moisture [69,70]. This different approach implies that with one approach, the existence of a precipitation period can generate a soil moisture behavior that could not be verified by another approach. This is often observed in water-limited environments, as is the case in much of the IP, where precipitation does not always cause significant changes in soil moisture evolution [71,72], especially when it is analyzed at the scale of the entire soil profile due to the existence of certain decoupling between the atmosphere and the soil system [73]. The increase in the frequency of low-precipitation events detected in Spain in recent decades [74] could also affect this dynamic.

Considering that soil plays an important role in relation to agricultural drought, as it is the reservoir from which plants are supplied, a trend analysis was also performed considering the soil characteristics. Thus, the evolution of the agricultural drought indices was analyzed according to soil textural fractions. The soil texture is largely responsible for porosity and plays an important role in hydraulic conductivity and soil water retention [75] and therefore in the availability of water for plants [76]. When agricultural drought trends were analyzed according to the sand content (Table 5), negative trends predominated for all textural percentage intervals. Therefore, no relationship was observed between the type of trend and the sand content of the soils (Figure 6). The percentage of cases with a negative trend ranged from $69.1 \%$ to $100 \%$ for the two indices calculated with the two soil moisture products and for the two temporal scales studied.

Table 5. Percentage of significant $(\mathrm{S})$, positive $(\mathrm{P})$, and negative $(\mathrm{N})$ trends at daily and weekly scales and by the sand content interval. Maximum trend percentage values are in bold.

\begin{tabular}{|c|c|c|c|c|c|c|c|c|c|c|c|c|}
\hline \multicolumn{13}{|c|}{ Anomalies } \\
\hline \multirow{3}{*}{$\begin{array}{c}\text { Sand } \\
(\%)\end{array}$} & \multicolumn{6}{|c|}{ Daily } & \multicolumn{6}{|c|}{ Weekly } \\
\hline & \multicolumn{3}{|c|}{ ERA } & \multicolumn{3}{|c|}{ LF } & \multicolumn{3}{|c|}{ ERA } & \multicolumn{3}{|c|}{ LF } \\
\hline & $S$ & $\mathbf{P}$ & $\mathbf{N}$ & $S$ & $\mathbf{P}$ & $\mathbf{N}$ & $S$ & $\mathbf{P}$ & $\mathbf{N}$ & $S$ & $\mathbf{P}$ & $\mathbf{N}$ \\
\hline$<10$ & 0.0 & 0.0 & 0.0 & 100.0 & 0.0 & 100.0 & 0.0 & 0.0 & 0.0 & 100.0 & 0.0 & 100.0 \\
\hline 10-20 & 73.5 & 11.1 & 88.9 & 87.1 & 16.5 & 83.5 & 46.9 & 4.3 & 95.7 & 69.8 & 17.7 & 82.3 \\
\hline $20-30$ & 88.4 & 3.5 & 96.5 & 83.4 & 24.6 & 75.4 & 69.0 & 1.5 & 98.5 & 64.8 & 22.3 & 77.7 \\
\hline $30-40$ & 85.6 & 3.1 & 96.9 & 89.4 & 21.5 & 78.5 & 69.9 & 0.7 & 99.3 & 74.0 & 18.2 & 81.8 \\
\hline $40-50$ & 76.1 & 2.9 & 97.1 & 87.9 & 30.9 & 69.1 & 49.8 & 0.4 & 99.6 & 70.4 & 28.7 & 71.3 \\
\hline$>50$ & 86.4 & 2.0 & 98.0 & 89.2 & 12.7 & 87.3 & 54.6 & 0.0 & 100.0 & 70.1 & 9.5 & 90.5 \\
\hline \multicolumn{13}{|c|}{ SWDI } \\
\hline$<10$ & 0.0 & 0.0 & 0.0 & 100.0 & 0.0 & 100.0 & 0.0 & 0.0 & 0.0 & 100.0 & 0.0 & 100.0 \\
\hline $10-20$ & 75.5 & 2.7 & 97.3 & 86.6 & 13.7 & 86.3 & 42.9 & 0.0 & 100.0 & 63.4 & 17.2 & 82.8 \\
\hline $20-30$ & 82.1 & 2.1 & 97.9 & 80.5 & 18.3 & 81.7 & 62.2 & 0.8 & 99.2 & 54.4 & 17.2 & 82.8 \\
\hline $30-40$ & 83.5 & 1.5 & 98.5 & 85.5 & 14.8 & 85.2 & 62.2 & 0.1 & 99.9 & 64.3 & 11.1 & 88.9 \\
\hline $40-50$ & 74.1 & 1.1 & 98.9 & 81.7 & 21.5 & 78.5 & 36.3 & 0.0 & 100.0 & 53.6 & 17.2 & 82.8 \\
\hline$>50$ & 78.3 & 0.9 & 99.1 & 85.1 & 6.5 & 93.5 & 28.3 & 0.0 & 100.0 & 58.3 & 5.2 & 94.8 \\
\hline
\end{tabular}




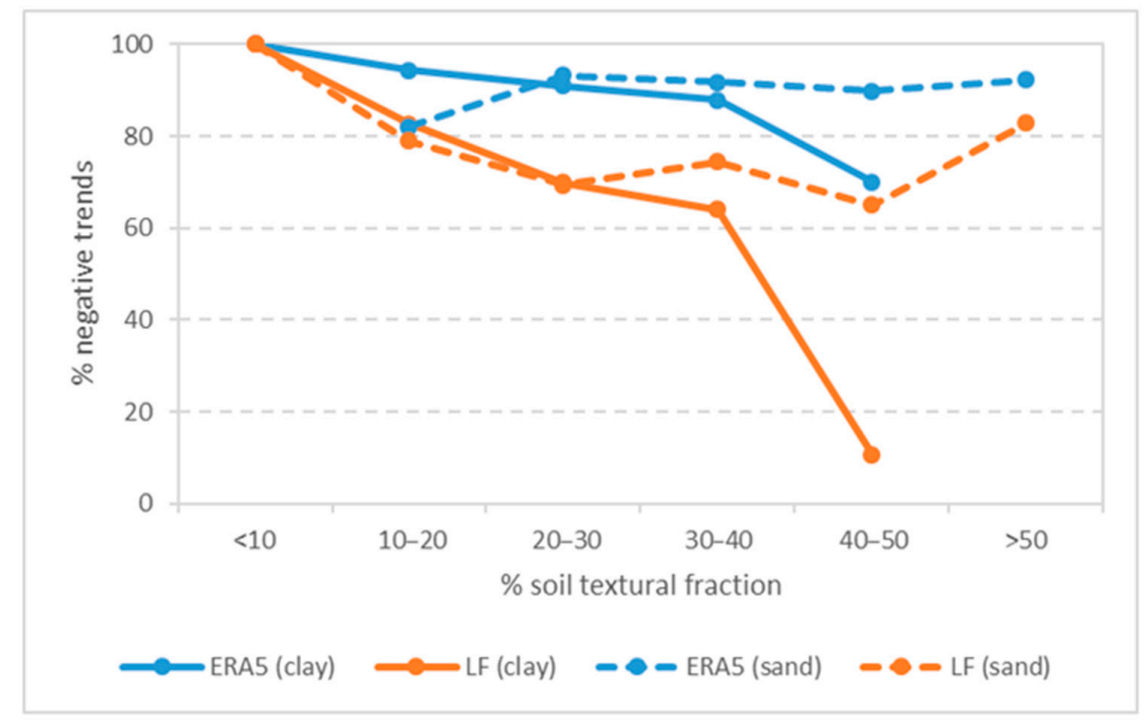

Figure 6. Relationship between the negative trends percentage (anomalies) and soil textural fraction percentage.

However, in the case of soil clay content (Table 6), although there is a clear predominance of negative trends similarly, a pattern of relationship is observed. As the clay fraction increases, the percentage of significant results and cases with a negative trend decrease to the point that for LF-calculated indices, a positive trend predominates for soils with clay content above $40 \%$. However, the percentage of territory with soils that have this high clay content is very low $(0.2 \%)$. This inverse relationship was observed for both agricultural indices and soil moisture products (Figure 6), although it is highlighted in the case of LF. The coincidence between areas of a positive trend with LF in summer months was mentioned above, with areas where the clay content is higher. These results are in accordance with the role of the clay fraction in the hydrological functioning of soils. As the clay content increases, the water retention capacity increases, and the hydraulic conductivity decreases. Therefore, water flow and transfer to the atmosphere are also reduced [75]. Clay content has been shown to play a significant role in soil water dynamics, even if its percentage is not very high [71,77].

Table 6. Percentage of significant $(\mathrm{S})$, positive $(\mathrm{P})$, and negative $(\mathrm{N})$ trends at daily and weekly scales and by the clay content interval. Maximum trend percentage values are in bold.

\begin{tabular}{|c|c|c|c|c|c|c|c|c|c|c|c|c|}
\hline \multicolumn{13}{|c|}{ Anomalies } \\
\hline \multirow{3}{*}{$\begin{array}{c}\text { Clay } \\
(\%)\end{array}$} & \multicolumn{6}{|c|}{ Daily } & \multicolumn{6}{|c|}{ Weekly } \\
\hline & \multicolumn{3}{|c|}{ ERA } & \multicolumn{3}{|c|}{ LF } & \multicolumn{3}{|c|}{ ERA } & \multicolumn{3}{|c|}{ LF } \\
\hline & $S$ & $\mathbf{P}$ & $\mathbf{N}$ & $S$ & $\mathbf{P}$ & $\mathbf{N}$ & $S$ & $\mathbf{P}$ & $\mathbf{N}$ & $S$ & $\mathbf{P}$ & $\mathbf{N}$ \\
\hline$<10$ & 100.0 & 0.0 & 100.0 & 100.0 & 0.0 & 100.0 & 55.6 & 0.0 & 100.0 & 94.7 & 0.0 & 100.0 \\
\hline $10-20$ & 85.1 & 1.0 & 99.0 & 90.7 & 13.6 & 86.4 & 58.4 & 0.0 & 100.0 & 75.6 & 11.3 & 88.7 \\
\hline $20-30$ & 83.1 & 3.2 & 96.8 & 88.1 & 25.9 & 74.1 & 63.7 & 0.6 & 99.4 & 70.6 & 23.1 & 76.9 \\
\hline $30-40$ & 78.3 & 5.9 & 94.1 & 83.0 & 30.2 & 69.8 & 48.2 & 3.0 & 97.0 & 63.3 & 27.7 & 72.3 \\
\hline $40-50$ & 57.1 & 12.5 & 87.5 & 80.6 & 88.0 & 12.0 & 35.7 & 0.0 & 100.0 & 48.4 & 100.0 & 0.0 \\
\hline \multicolumn{13}{|c|}{ SWDI } \\
\hline$<10$ & 100.0 & 0.0 & 100.0 & 100.0 & 0.0 & 100.0 & 0.0 & 0.0 & 0.0 & 94.7 & 0.0 & 100.0 \\
\hline $10-20$ & 79.8 & 0.4 & 99.6 & 87.5 & 7.9 & 92.1 & 34.0 & 0.0 & 100.0 & 62.8 & 6.2 & 93.8 \\
\hline $20-30$ & 80.5 & 1.3 & 98.7 & 83.0 & 17.9 & 82.1 & 54.6 & 0.1 & 99.9 & 58.3 & 13.7 & 86.3 \\
\hline 30-40 & 72.4 & 3.7 & 96.3 & 78.5 & 22.1 & 77.9 & 41.3 & 0.9 & 99.1 & 51.6 & 22.0 & 78.0 \\
\hline $40-50$ & 50.0 & 14.3 & 85.7 & 71.0 & 77.3 & 22.7 & 7.1 & 0.0 & 100.0 & 35.5 & 100.0 & 0.0 \\
\hline
\end{tabular}


This predominance of negative trends in agricultural drought in the IP that have been observed over the past four decades has to be analyzed in view of the climate context that occurred in that period. In recent decades, there has been no clear trend in precipitation, both in Spain [78] or Portugal [79] or even during the last century [80], as was observed in all of Southwestern Europe [81]. This lack of precipitation trends was observed both in the amount and in the intensity of precipitation [82]. However, an increase in temperature that has been clearly detected globally has also been observed on the IP [83,84], even with very significant rates of up to $0.2^{\circ} \mathrm{C}$ per decade [85]. This temperature increase is linked to a positive trend in evapotranspiration [86] and has a direct impact on soil water dynamics.

Therefore, if the amount of precipitation or its distribution has not changed but the temperature and thus evapotranspiration have experienced a noticeable increase, then an increase in aridity [87] and a negative evolution of the soil water balance are expected. This evolution appears to be reflected in the results of the analysis of the agricultural drought trends carried out over the IP. What has been observed in recent decades shows a troubling picture for agriculture in IP, but what is inferred from the different climate change scenarios makes the near future even more disturbing. In recent studies, the evolution of agricultural drought indicators showed how drought frequency, duration, and intensity will increase over the present century [17].

There is another process that is occurring in parallel with global warming and could contribute to the evolution of soil moisture and therefore agricultural drought in many areas of the IP, and in the same direction that the climate evolution and the results of the trend analysis point out. This is the abandonment of rural areas as a consequence of the depopulation that has been affecting large areas of Spain [88], Portugal [89], and all of Europe [90] in recent decades and will continue affecting in the next ones [91]. This abandonment has led to unprecedented vegetation regeneration and recovery of forested area [92]. It is well known that the type of land use and plant cover influences the dynamics and storage of soil moisture [93]. Under the same soil and bioclimatic conditions, a soil covered with herbaceous vegetation will retain and store more water than another covered with forest $[94,95]$. Therefore, this process of substitution of crops or pasture by permanent vegetation and, finally, forest, could also influence a gradual reduction in the soil water content in the areas affected by land abandonment.

This study has shown widespread predominance of negative trends in agricultural drought indices, which have primarily been detected for the period April-May to October. This period has great relevance considering that it coincides with the growing season of the main crops of the IP [96] and with the dry season in countries with a Mediterranean climate. This implies that an increase in soil water deficit occurs during the season of less water availability. This evolution could further restrict the conditions of rainfed agriculture, increase the need to increase the irrigation area to maintain productivity, and increase water consumption in the pre-existing irrigated areas [97]. This could mean a noticeable change in water resources management and a potential negative impact on natural water-linked systems [98]. Although some countries, such as Spain [99], have experienced a very positive evolution in the use of more efficient irrigation technologies, more effort and investment will still need to be made in this field. What is undoubted is that the impact of climate change is very evident and it is intensifying agricultural drought in regions such as the IP, where the rainfed area will remain the main part of the agricultural land.

\section{Conclusions}

Many studies in recent years, in addition to the findings of the IPCC analysis, prove that Southern Europe is expected to be particularly vulnerable to climate change. Therefore, studies on the evolution of processes directly affected by this major environmental problem are of great interest. Agricultural drought is at the heart of this interest. On the one hand, as it is a phenomenon in which water plays a prominent role and therefore is directly involved in many negative issues related to climate change. On the other hand, it is a natural hazard that affects aspects as sensitive as agricultural production and food security. 
The Mediterranean region, particularly those countries relying on rainfed agricultural production, is especially vulnerable to these constraints triggered by agricultural drought and the observed evolution of the climate system.

The results of the study of agricultural drought trends on the IP over the past four decades have revealed a clear negative trend. Therefore, over this period, agricultural drought has become increasingly common. Whether using soil moisture anomalies, which are a mere statistical indicator, or using the SWDI, which is an index that expresses soil water availability for plants, have obtained similar results. In all cases, the number of significant trends was very high and more than $75 \%$ were negative. Substantial differences were also not observed when the analysis became specific to the climatic zones obtained by the classification of Köppen-Geiger. Regardless of the climatic characteristics of each zone, negative trends in agricultural drought predominate across the IP, which is consistent with the vulnerability to the climate drift of Mediterranean regions as a whole.

A temporal pattern was obtained from the results of the analysis throughout the months of the year. Despite some differences observed between the results of LF and ERA5, especially from May-July, and probably related to the specificity of the two soil moisture products used, the results were very similar. For both agricultural drought indicators, during 10 consecutive months, the negative trends were predominant and positive in 2 months. This finding is especially relevant since those months with a negative trend predominance coincide with the growing season of most of the crops of the IP. This indicates that for these crops, there is a clear decrease in the water available in the soil, just at the time when they need it most. The lower availability of water in this season is a defining feature of the Mediterranean climate. However, the results indicate that scarcity, water deficit and, therefore, water stress are being accentuated over time.

Soil is the reservoir from which crops are supplied with water. Therefore, it is interesting to determine whether there is any relationship between the evolution of agricultural drought and soil characteristics. Soil texture was the attribute that was chosen due to its enormous influence on the dynamics of soil moisture. A predominance of negative trends was obtained for all textural fractions. In the case of sand content, no related pattern was observed, and the results were similar for all textural intervals. However, a pattern for clay was obtained, so that as its content increased, the percentage of negative trends decreased. This is in line with the behavior of clay soils in relation to water flow and retention capacity.

The results of the analysis of agricultural drought trends on the IP must be interpreted in view of the evolution of climate variables and the evolution of land use that have been observed in this region in recent decades. All these changes directly and negatively affect the soil water balance. Therefore, and if this continues, as climate change projections point out, the agriculture of the IP will be seriously affected in the coming years. Not only rainfed agriculture, which directly depends on the water that supplies the atmosphere and is stored in the soil, but also irrigation since the water demand will increase. Currently, approximately three-quarters of the water demand on the IP is used in agriculture. Therefore, the results of this study can be useful for properly planning water management in agriculture and implementing appropriate climate change adaptation measures.

Author Contributions: The initial idea for this research was conceived by J.M.-F.; the different dataset were prepared by Á.G.-Z. and L.A.-M., who also collected all the results; J.M.-F., Á.G.-Z., P.B.-V., C.M.H.-J. and L.A.-M. have equally contributed to the analysis and the interpretation of the results; the first manuscript was prepared by L.A.-M. and J.M.-F., in collaboration with the other authors. All the authors revised the final manuscript and approved it. All authors have read and agreed to the published version of the manuscript.

Funding: This study was supported by the Spanish Ministry of Science, Innovation and Universities (project ESP2017-89463-C3-3-R), the Castilla y León Government (Projects SA112P20 and Unidad de Excelencia CLU-2018-04), and the European Regional Development Fund.

Institutional Review Board Statement: Not applicable.

Informed Consent Statement: Not applicable. 


\section{Data Availability Statement: Not applicable.}

Acknowledgments: The authors acknowledge the European Space Agency, the ISRIC-World Soil Information, the ECMWF Copernicus, and the European Flood Awareness System.

Conflicts of Interest: The authors declare no conflict of interest.

\section{References}

1. Wilhite, D. Drought as a natural hazard: Concepts and definitions. In Droughts: Global Assessment; Wilhite, D.A., Ed.; Routledge: London, UK, 2000; pp. 3-18.

2. Adikari, Y.; Yoshitani, J. Global Trends in Water-Related Disasters: An Insight for Policymakers; UNESCO: Paris, France, 2009; 24p.

3. Li, X.; Wang, X.; Babovic, V. Analysis of variability and trends of precipitation extremes in Singapore during 1980-2013. Int. J. Climatol. 2018, 38, 125-141. [CrossRef]

4. Trenberth, K.E. Changes in precipitation with climate change. Clim. Res. 2011, 47, 123-138. [CrossRef]

5. Haile, G.G.; Tang, Q.; Hosseini-Moghari, S.M.; Liu, X.; Gebremicael, T.G.; Leng, G.; Kebede, A.; Xu, X.; Yun, X. Projected impacts of climate change on drought patterns over East Africa. Earths Future 2020, 8, e2020EF001502. [CrossRef]

6. Mishra, A.K.; Singh, V.P. A review of drought concepts. J. Hydrol. 2010, 391, 202-216. [CrossRef]

7. Panu, U.S.; Sharma, T.C. Challenges in drought research: Some perspectives and future directions. Hydrol. Sci. J. 2002, 47, S19-S30. [CrossRef]

8. Boyer, J.S. Plant productivity and environment. Science 1982, 218, 443-448. [CrossRef] [PubMed]

9. Enenkel, M.; See, L.; Bonifacio, R.; Boken, V.; Chaney, N.; Vinck, P.; You, L.; Dutra, E.; Anderson, M. Drought and food security-Improving decision-support via new technologies and innovative collaboration. Glob. Food Secur. 2015, 4, 51-55. [CrossRef]

10. Kelley, C.P.; Mohtadi, S.; Cane, M.A.; Seager, R.; Kushnir, Y. Climate change in the Fertile Crescent and implications of the recent Syrian drought. Proc. Natl. Acad. Sci. USA 2015, 112, 3241-3246. [CrossRef]

11. Low, A.J.; Frederix, K.; McCracken, S.; Manyau, S.; Gummerson, E.; Radin, E.; DaviaI, S.; Longwe, H.; Ahmed, N.; Parekh, B.; et al. Association between severe drought and HIV prevention and care behaviors in Lesotho: A population-based survey $2016-2017$. PLoS Med. 2019, 16, e1002727. [CrossRef]

12. Giorgi, F.; Lionello, P. Climate change projections for the Mediterranean region. Glob. Planet. Chang. 2008, 63, 90-104. [CrossRef]

13. Tramblay, Y.; Koutroulis, A.; Samaniego, L.; Vicente-Serrano, A.M.; Volaire, F.; Boone, A.; Le Page, M.; Llasat, M.C.; Albergel, C.; Burak, S.; et al. Challenges for drought assessment in the Mediterranean region under future climate scenarios. Earth Sci. Rev. 2020, 210, 103348. [CrossRef]

14. IPCC. Summary for Policymakers. In Fifth Assessment Report of the Intergovernmental Panel on Climate Change; Cambridge University Press: Cambridge, UK, 2014.

15. Páscoa, P.; Gouveia, C.M.; Russo, A.; Trigo, R.M. Drought Trends in the Iberian Peninsula over the Last 112 Years. Adv. Meteorol. 2017, 4653126

16. Divrak, B.B.; Ayas, C.; Iş, G. Drought trends and impacts on agricultural production and natural resources in the context of climate change. In Economics of Drought and Drought Preparedness in a Climate Change Context; López-Francos, A., Ed.; Série A. Séminaires Méditerranéens; Options Méditerranéennes: Turkey, Istanbul, 2010; Volume 95, pp. 49-55.

17. Jiménez-Donaire, M.P.; Giráldez, J.V.; Vanwalleghem, T. Impact of Climate Change on Agricultural Droughts in Spain. Water 2020, 12, 3214. [CrossRef]

18. Peña-Gallardo, M.; Vicente-Serrano, S.M.; Domínguez-Castro, F.; Beguería, S. The impact of drought on the productivity of two rainfed crops in Spain. Nat. Hazards Earth Syst. Sci. 2019, 19, 1215-1234. [CrossRef]

19. Bouras, E.H.; Jarlan, 1.; Er-Raki, S.; Albergel, C.; Richard, B.; Balaghi, R.; Khabba, S. Linkages between Rainfed Cereal Production and Agricultural Drought through Remote Sensing Indices and a Land Data Assimilation System: A Case Study in Morocco. Remote Sens. 2020, 12, 4018. [CrossRef]

20. Eurostat. Farms and Farmland in the European Union-Statistics; Eurostat: Luxembourg, 2019.

21. Fernández-Nogueira, D.; Corbelle-Rico, E. Land Use Changes in Iberian Peninsula 1990-2012. Land 2018, 7, 99. [CrossRef]

22. Bradford, J.B.; Schlaepfer, D.R.; Lauenroth, W.K.; Yackulic, C.B.; Duniway, M.; Hall, S.; Jia, G.; Jamiyansharav, K.; Munson, S.M.; Wilson, S.D.; et al. Future soil moisture and temperature extremes imply expanding suitability for rainfed agriculture in temperate drylands. Sci. Rep. 2017, 7, 12923. [CrossRef]

23. Allen, R.G.; Pereira, L.S.; Raes, D.; Smith, M. Crop Evapotranspiration: Guidelines for Computing Crop Water Requirements-FAO Irrigation and Drainage Paper 56; FAO: Rome, Italy, 1998.

24. Torres, G.M.; Lollato, P.R.; Ochsner, T.E. Comparison of drought probability assessments based on atmospheric water deficit and soil water deficit. Agron. J. 2013, 105, 428-436. [CrossRef]

25. Martínez-Fernández, J.; González-Zamora, A.; Sánchez, N.; Gumuzzio, A. A soil water based index as a suitable agricultural drought indicator. J. Hydrol. 2015, 522, 265-273. [CrossRef]

26. Mladenova, I.E.; Bolten, J.D.; Crow, W.; Sazib, N.; Reynolds, C. Agricultural drought monitoring via the assimilation of SMAP soil moisture retrievals into a Global Soil Water Balance Model. J. Big Data 2020, 3, 10. [CrossRef] 
27. Sawada, Y. Quantifying drought propagation from soil moisture to vegetation dynamics using a newly developed ecohydrological land reanalysis. Remote Sens. 2018, 10, 1197. [CrossRef]

28. Pablos, M.; Martínez-Fernández, J.; Sánchez, N.; González-Zamora, A. Temporal and Spatial Comparison of Agricultural Drought Indices from Moderate Resolution Satellite Soil Moisture Data over Northwest Spain. Remote Sens. 2017, 9, 1168. [CrossRef]

29. Martínez-Fernández, J.; González-Zamora, A.; Sánchez, N.; Gumuzzio, A.; Herrero-Jiménez, C.M. Satellite soil moisture for agricultural drought monitoring: Assessment of the SMOS derived Soil Water Deficit Index. Remote Sens. Environ. 2016, 177, 277-286. [CrossRef]

30. Sánchez, N.; González-Zamora, A.; Piles, M.; Martínez-Fernández, J. A New Soil Moisture Agricultural Drought Index (SMADI) Integrating MODIS and SMOS Products: A Case of Study over the Iberian Peninsula. Remote Sens. 2016, 8, 287. [CrossRef]

31. Baik, J.; Zohaib, M.; Kim, U.; Aadil, M.; Choi, M. Agricultural drought assessment based on multiple soil moisture products. J. Arid Environ. 2019, 167, 43-55. [CrossRef]

32. Dorigo, W.A.; Gruber, A.; de Jeu, R.A.M.; Wagner, W.; Stacke, T.; Loew, A.; Albergel, C.; Brocca, L.; Chung, D.; Parinussa, R.M.; et al. Evaluation of the ESA CCI soil moisture product using ground-based observations. Remote Sens. Environ. 2015, 162, 380-395. [CrossRef]

33. Dee, D.P.; Uppala, S.; Simmons, A.; Berrisford, P.; Poli, P.; Kobayashi, S.; Andrae, U.; Balmaseda, M.; Balsamo, G.; Bauer, P. The ERA-interim reanalysis: Configuration and performance of the data assimilation system. Q. J. R. Meteorol. Soc. 2011, 137, 553-597. [CrossRef]

34. Naz, B.S.; Kollet, S.; Hendricks Franssen, H.J.; Montzka, C.; Kurtz, W. A 3 km spatially and temporally consistent European daily soil moisture reanalysis from 2000 to 2015. Sci. Data 2020, 7, 111. [CrossRef]

35. Martínez-Fernández, J.; Almendra-Martín, L.; de Luis, M.; González-Zamora, A.; Herrero-Jiménez, C.M. Tracking tree growth through satellite soil moisture monitoring: A case study of Pinus halepensis in Spain. Remote Sens. Environ. 2019, $235,111422$. [CrossRef]

36. González-Zamora, A.; Sánchez, N.; Pablos, M.; Martínez-Fernández, J. CCI soil moisture assessment with SMOS soil moisture and in situ data under different environmental conditions and spatial scales in Spain. Remote Sens. Environ. 2019, 225, 469-482. [CrossRef]

37. Balsamo, G.; Albergel, C.; Beljaars, A.; Boussetta, S.; Brun, E.; Cloke, H.; Dee, D.; Dutra, E.; Muñoz-Sabater, J.; Pappenberger, F.; et al. ERA-Interim/Land: A global land surface reanalysis data set. Hydrol. Earth Syst. Sci. 2015, 19, 389-407. [CrossRef]

38. Cammalleri, C.; Micale, F.; Vogt, J. Recent temporal trend in modelled soil water deficit over Europe driven by meteorological observations. Int. J. Climatol. 2016, 36, 4903-4912. [CrossRef]

39. Albergel, C.; Dorigo, W.; Reichle, R.H.; Balsamo, G.; De Rosnay, P.; Muñoz-Sabater, J.; Isaksen, L.; de Jeu, R.; Wagner, W. Skill and global trend analysis of soil moisture from reanalyses and microwave remote sensing. J. Hydrometeorol. 2013, 14, 1259-1277. [CrossRef]

40. Beck, H.E.; Pan, M.; Miralles, D.G.; Reichle, R.H.; Dorigo, W.A.; Hahn, S.; Sheffield, J.; Karthikeyan, L.; Balsamo, G.; Parinussa, R.M.; et al. Evaluation of 18 satellite- and model-based soil moisture products using in situ measurements from 826 sensors. Hydrol. Earth Syst. Sci. 2021, 25, 17-40. [CrossRef]

41. de Roo, A.P.J.; Wesseling, C.G.; van Deursen, W.P.A. Physically based river basin modelling within a GIS: The LISFLOOD model. Hydrol. Process 2000, 14, 1981-1992. [CrossRef]

42. Thielen, J.; Bartholmes, J.; Ramos, M.H.; de Roo, A. The European Flood Alert System-Part 1: Concept and development. Hydrol. Earth Syst. Sci. 2009, 13, 125-140. [CrossRef]

43. van der Knijff, J.M.; Younis, J.; de Roo, A.P.J. LISFLOOD: A GIS-based distributed model for river basin scale water balance and flood simulation. Int. J. Geogr. Inf. Sci. 2008, 24, 189-212. [CrossRef]

44. Siebert, S.; Döll, P.; Hoogeveen, J.; Faures, J.M.; Frenken, K.; Feick, S. Development and validation of the global map of irrigation areas. Hydrol. Earth Syst. Sci. 2005, 9, 535-547. [CrossRef]

45. Beck, H.E.; Zimmermann, N.E.; McVicar, T.R.; Vergopolan, N.; Berg, A.; Wood, E.F. Present and future Köppen-Geiger climate classification maps at 1-km resolution. Sci. Data 2018, 5, 180214. [CrossRef] [PubMed]

46. Kottek, M.; Rubel, F.; Grieser, J.; Beck, C.; Rudolf, B. World map of the Koeppen-Geiger climate classification updated. Meteorol. Z. 2006, 15, 259-263. [CrossRef]

47. Rubel, F.; Brugger, K.; Haslinger, K.; Auer, I. The climate of the European Alps: Shift of very high resolution Köppen-Geiger climate zones 1800-2100. Meteorol. Z. 2017, 26, 115-125. [CrossRef]

48. Peel, M.C.; Finlayson, B.L.; McMahon, T.A. Updated world map of the Köppen-Geiger climate classification. Hydrol. Earth Syst. Sci. 2007, 11, 1633-1644. [CrossRef]

49. Batjes, N.H.; Ribeiro, E.; van Oostrum, Ad. Standardised soil profile data to support global mapping and modelling (WoSIS snapshot 2019). Earth Syst. Sci. Data 2020, 12, 299-320. [CrossRef]

50. Saxton, K.E.; Rawls, W.J. Soil water characteristic estimates by texture and organic matter for hydrologic solutions. Soil Sci. Soc. Am. J. 2006, 70, 1569-1578. [CrossRef]

51. Elagib, N.A.; Elhag, M.M. Major climate indicators of ongoing drought in Sudan. J. Hydrol. 2011, 409, 612-625. [CrossRef]

52. Sepulcre-Canto, G.; Horion, S.M.A.F.; Singleton, A.; Carrao, H.; Vogt, J. Development of a Combined Drought Indicator to detect agricultural drought in Europe. Nat. Hazards Earth Syst. Sci. 2012, 12, 3519-3531. [CrossRef] 
53. Steinemann, A.; Iacobellis, S.F.; Cayan, D.R. Developing and evaluating drought indicators for decision-making. J. Hydrometeorol. 2015, 16, 1793-1803. [CrossRef]

54. Purcell, L.C.; Sinclair, T.R.; McNew, R.W. Drought avoidance assessment for summer annual crops using long-term weather data. Agron. J. 2003, 95, 1566-1576. [CrossRef]

55. Király, A.; Bartos, I.; Jánosi, I.M. Correlation properties of daily temperature anomalies over land. Tellus A Dyn. Meteorol. Oceanogr. 2006, 58, 593-600. [CrossRef]

56. Wongsai, N.; Wongsai, S.; Huete, A.R. Annual seasonality extraction using the cubic spline function and decadal trend in temporal daytime MODIS LST data. Remote Sens. 2017, 9, 1254. [CrossRef]

57. Savage, M.J.; Ritchie, J.T.; Bland, W.L.; Dugas, W.A. Lower limit of soil water availability. Agron. J. 1996, 88, 644-651. [CrossRef]

58. Mann, H.B. Nonparametric tests against trend. Econometrica 1945, 13, 245-259. [CrossRef]

59. Kendall, M.G. Rank Correlation Methods; Griffin: London, UK, 1948.

60. Qiu, J.; Gao, Q.; Wang, S.; Su, Z. Comparison of temporal trends from multiple soil moisture data sets and precipitation: The implication of irrigation on regional soil moisture trend. Int. J. Appl. Earth Obs. Geoinf. 2016, 48, 17-27. [CrossRef]

61. Yue, S.; Pilon, P.; Cavadias, G. Power of the Mann-Kendall and Spearman's rho tests for detecting monotonic trends in hydrological series. J. Hydrol. 2002, 259, 254-271. [CrossRef]

62. Yue, S.; Hashino, M. Temperature trends in Japan: 1900-1996. Theor. Appl. Climatol. 2003, 75, 15-27. [CrossRef]

63. Zhang, X.; Vincent, L.A.; Hogg, W.D.; Niitsoo, A. Temperature and precipitation trends in Canada during the 20th century. Atmos. Ocean 2000, 38, 395-429. [CrossRef]

64. Hamed, K.H.; Rao, A.R. A modified Mann-Kendall trend test for autocorrelated data. J. Hydrol. 1998, 204, 182-196. [CrossRef]

65. Şen, Z. Hydrological trend analysis with innovative and over-whitening procedures. Hydrol. Sci. J. 2017, 62, 294-305. [CrossRef]

66. Hirsch, R.M.; Slack, J.R. A nonparametric trend test for seasonal data with serial dependence. Water Resour. Res. 1984, $20,727-732$. [CrossRef]

67. Yue, S.; Wang, C.Y. Applicability of prewhitening to eliminate the influence of serial correlation on the Mann-Kendall test. Water Resour. Res. 2002, 38, 1068. [CrossRef]

68. Cammalleri, C.; Vogt, J.V.; Bisselink, B.; de Roo, A. Comparing soil moisture anomalies from multiple independent sources over different regions across the globe. Hydrol. Earth Syst. Sci. 2017, 21, 6329-6343. [CrossRef]

69. Hersbach, H.; Bell, B.; Berrisford, P.; Hirahara, S.; Horányi, A.; Muñoz-Sabater, J.; Nicolas, J.; Peubey, C.; Radu, R.; Schepers, D.; et al. The ERA5 global reanalysis. Q. J. R. Meteorol. Soc. 2020, 146, 1999-2049. [CrossRef]

70. Li, M.; Wu, P.; Ma, Z. A comprehensive evaluation of soil moisture and soil temperature from third-generation atmospheric and land reanalysis data sets. Int. J. Climatol. 2020, 40, 5744-5766. [CrossRef]

71. Ceballos, A.; Martínez-Fernández, J.; Santos, F.; Alonso, P. Soil water behaviour of sandy soils under semiarid conditions in the Duero Basin (Spain). J. Arid Environ. 2002, 51, 501-519. [CrossRef]

72. Ceballos, A.; Martínez-Fernández, J.; Luengo-Ugidos, M.A. Analysis of rainfall trends and dry periods on a pluviometric gradient representative of Mediterranean climate in the Duero Basin, Spain. J. Arid Environ. 2004, 58, 214-232. [CrossRef]

73. Martínez-Fernández, J.; González-Zamora, A.; Almendra-Martín, L. Soil moisture memory and soil properties: An analysis with the stored precipitation fraction. J. Hydrol. 2020. In Press. [CrossRef]

74. Serrano-Notivoli, R.; Beguería, S.; Saz, M.A.; de Luis, M. Recent trends reveal decreasing intensity of daily precipitation in Spain. Int. J. Climatol. 2018, 38, 4211-4224. [CrossRef]

75. Kutilek, M.; Nielsen, D.R. Soil Hydrology; Catena, Ed.; Schweizerbart Science Publishers: Germany, Stuttgart, 1994.

76. Kirkham, M.B. Field capacity, wilting point, available water, and the non-limiting water range. In Principles of Soil and Plant Water Relations; Academic Press: Cambridge, MA, USA, 2005; pp. 101-115.

77. Saxton, K.E.; Rawls, W.J.; Romberger, J.S.; Papendick, R.I. Estimating generalized soil water characteristics from texture. Trans. ASAE 1986, 50, 1031-1035.

78. González-Hidalgo, J.C.; Brunetti, M.; de Luis, M. Precipitation trends in Spanish hydrological divisions, 1946-2005. Clim. Res. 2010, 43, 215-228. [CrossRef]

79. Paulo, A.A.; Rosa, R.D.; Pereira, L.S. Climate trends and behaviour of drought indices based on precipitation and evapotranspiration in Portugal. Nat. Hazards Earth Syst. Sci. 2012, 12, 1481-1491. [CrossRef]

80. Andreo, B.; Jiménez, P.; Durán, J.J.; Carrasco, F.; Vadillo, I.; Mangin, A. Climatic and hydrological variations during the last 117-166 years in the south of the Iberian Peninsula, from spectral and correlation analyses and continuous wavelet analyses. $J$. Hydrol. 2006, 324, 24-39. [CrossRef]

81. Peña-Angulo, D.; Vicente-Serrano, S.M.; Domínguez-Castro, F.; Murphy, C.; Reig, F.; Tramblay, Y.; Trigo, R.M.; Luna, M.Y.; Turco, M.; Noguera, I.; et al. Long-term precipitation in Southwestern Europe reveals no clear trend attributable to anthropogenic forcing. Environ. Res. Lett. 2020, 15, 094070. [CrossRef]

82. Rodrigo, F.S.; Trigo, R.M. Trends in daily rainfall in the Iberian Peninsula from 1951 to 2002. Int. J. Climatol. 2007, 27, 513-529. [CrossRef]

83. López-Moreno, J.I.; Vicente-Serrano, S.M.; Morán-Tejeda, E.; Zabalza, J.; Lorenzo-Lacruz, J.; García-Ruiz, J.M. Impact of climate evolution and land use changes on water yield in the Ebro basin. Hydrol. Earth Syst. Sci. 2011, 15, 311-322. [CrossRef]

84. Espírito Santo, F.; de Lima, M.I.; Ramos, A.M.; Trigo, R.M. Trends in seasonal surface air temperature in mainland Portugal, since 1941. Int. J. Climatol. 2014, 34, 1814-1837. [CrossRef] 
85. Del Río, S.; Herrero, L.; Pinto-Gomes, C.; Penas, A. Spatial analysis of mean temperature trends in Spain over the period $1961-2006$. Glob. Planet. Change 2011, 78, 65-75. [CrossRef]

86. Vicente-Serrano, S.M.; Azorín-Molina, C.; Sánchez-Lorenzo, A.; Revuelto, J.; López-Moreno, J.; González-Hidalgo, J.C.; MoránTejeda, E.; Espejo, F. Reference evapotranspiration variability and trends in Spain, 1961-2011. Glob. Planet. Change 2014, 121, 26-40. [CrossRef]

87. Paniagua, L.L.; García-Martín, A.; Moral, F.J.; Rebollo, F.J. Aridity in the Iberian Peninsula (1960-2017): Distribution, tendencies, and changes. Theor. Appl. Climatol. 2019, 138, 811-830. [CrossRef]

88. Lasanta, T.; Arnáez, J.; Pascual, N.; Ruiz-Flaño, P.; Errea, M.P.; Lana-Renault, N. Space-time process and drivers of land abandonment in Europe. Catena 2017, 149, 810-823. [CrossRef]

89. van der Zanden, E.H.; Carvalho-Ribeiro, S.M.; Verburg, P.H. Abandonment landscapes: User attitudes, alternative futures and land management in Castro Laboreiro, Portugal. Reg. Environ. Change 2018, 18, 1509-1520. [CrossRef]

90. Verburg, P.H.; Schulp, C.J.E.; Witte, N.; Veldkamp, A. Downscaling of land use change scenarios to assess the dynamics of European landscapes. Agric. Ecosyst. Environ. 2006, 114, 39-56. [CrossRef]

91. Perpiñá Castillo, C.; Coll Aliaga, E.; Lavalle, C.; Martínez Llario, J.C. An Assessment and Spatial Modelling of Agricultural Land Abandonment in Spain (2015-2030). Sustainability 2020, 12, 560. [CrossRef]

92. Forest Europe; UNECE; FAO. State of Europe's Forests 2011 Status \& Trends in Sustainable Forest Management in Europe. Roman Michalak (Coord.). In Ministerial Conference on the Protection of Forests in Europe; FOREST EUROPE Liaison Unit Oslo: Aas, Norway, 2011; p. 337.

93. Green, J.C.; Reid, I.; Calder, I.R.; Nisbet, T.R. Four-year comparison of water contents beneath a grass ley and a deciduous oak wood overlaying Triassic sandstone in lowland England. J. Hydrol. 2006, 329, 16-25. [CrossRef]

94. Roberts, J. and Rosier, P. The impact of broadleaved woodland on water resources in lowland UK: III. The results from Black Wood ad Bridgets Farm compared with those from other woodland and grassland sites. Hydrol. Earth Sys. Sci. 2005, 9, 614-620. [CrossRef]

95. Martínez-Fernández, J.; Hernández-Santana, V.; Morán-Tejeda, C.; Casado-Ledesma, S. Soil water availability under different Mediterranean land uses in Spain. In Soil and Water Conservation under Changing Land Use; Martínez-Casasnovas, J.A., Pla Sentís, I., Ramos Martín, M.C., Balasch Solanes, J.C., Eds.; Edicions de la Universitat de Lleida: Lleida, Spain, 2006; pp. 93-96.

96. Capa-Morocho, M.; Inés, A.V.N.; Baethgen, W.E.; Rodríguez-Fonseca, B.; Han, E.; Ruiz-Ramos, M. Crop yield outlooks in the Iberian Peninsula: Connecting seasonal climate forecasts with crop simulation models. Agric. Syst. 2016, 149, 75-87. [CrossRef]

97. Elliott, J.; Deryng, D.; Müller, C.; Frieler, K.; Konzmann, M.; Gerten, D.; Glotter, M.; Flörke, M.; Wada, Y.; Best, N.; et al. Constraints and potentials of future irrigation water availability on agricultural production under climate change. Proc. Natl. Acad. Sci. USA 2014, 111, 3239-3244. [CrossRef] [PubMed]

98. Perret, S.R.; Payen, S. Irrigation and the environmental tragedy: Pathways towards sustainability in agricultural water use. Irrig. Drain. 2020, 69, 263-271. [CrossRef]

99. Incrocci, L.; Thompson, R.B.; Fernandez-Fernandez, M.D.; de Pascale, S.; Pardossi, A.; Stanghellini, C.; Rouphael, Y.; Gallardo, M. Irrigation management of European greenhouse vegetable crops. Agric. Water Manag. 2020, 242, 106393. [CrossRef] 